\title{
Cigarette Smoke Exposure Promotes Arterial Thrombosis and Vessel Remodeling after Vascular Injury in Apolipoprotein E-Deficient Mice
}

\author{
Marco R. Schroeter ${ }^{\mathrm{a}}$ Matthias Sawalich ${ }^{\mathrm{a}}$ Tim Humboldt $^{\mathrm{a}}$ Maren Leifheit $^{\mathrm{a}}$ \\ Kris Meurrens ${ }^{c}$ An Berges ${ }^{c}$ Haiyan $\mathrm{Xu}^{c}$ Stefan Lebrun ${ }^{d}$ Thomas Wallerath $^{\mathrm{b}}$ \\ Stavros Konstantinides ${ }^{a}$ Raymond Schleef ${ }^{e}$ Katrin Schaefer ${ }^{a}$ \\ ${ }^{a}$ Department of Cardiology and Pulmonary Medicine, Georg August University of Göttingen, Göttingen, and

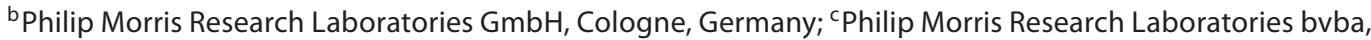

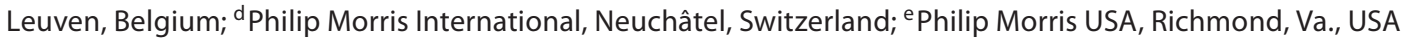

\section{Key Words}

Arterial thrombosis $\cdot$ ApoE knockout mice $\cdot$ Smoking $\cdot$

Neointima formation $\cdot$ Smooth muscle cells

\begin{abstract}
Background: Cigarette smoking is a major risk factor for the development of cardiovascular disease. However, in terms of the vessel wall, the underlying pathomechanisms of cigarette smoking are incompletely understood, partly due to a lack of adequate in vivo models. Methods: Apolipoprotein E-deficient mice were exposed to filtered air (sham) or to cigarette mainstream smoke at a total particulate matter (TPM) concentration of $600 \mu \mathrm{g} / \mathrm{l}$ for 1, 2, 3, or $4 \mathrm{~h}$, for 5 days/week. After exposure for $10 \pm 1$ weeks, arterial thrombosis and neointima formation at the carotid artery were induced using 10\% ferric chloride. Results: Mice exposed to mainstream smoke exhibited shortened time to thrombotic occlusion $(p<0.01)$ and lower vascular patency rates $(p<0.001)$. Morphometric and immunohistochemical analysis of neointimal lesions demonstrated that mainstream smoke exposure increased the amount of $\alpha$-actin-positive smooth muscle cells ( $p<0.05)$ and dose-dependently increased the intima-to-
\end{abstract}

\section{KARGER \\ Fax +4161306 1234 \\ E-Mail karger@karger.ch}

www.karger.com (c) 2008 S. Karger AG, Basel

$1018-1172 / 08 / 0456-0480 \$ 24.50 / 0$

Accessible online at:

www.karger.com/jvr media ratio $(p<0.05)$. Additional analysis of smooth muscle cells in vitro suggested that $10 \mu \mathrm{g}$ TPM/ml increased cell proliferation without affecting viability or apoptosis, whereas higher concentrations (100 and $500 \mu \mathrm{g}$ TPM/ml) appeared to be cytotoxic. Conclusions: Taken together, these findings suggest that cigarette smoking promotes arterial thrombosis and modulates the size and composition of neointimal lesions after arterial injury in apolipoprotein E-deficient mice.

Copyright $\odot 2008$ S. Karger AG, Basel

\section{Introduction}

Cigarette smoking has long been recognized as a major risk factor for enhanced atherosclerosis progression and acute arterial thrombosis $[1,2]$. For example, an estimated 1.6 million cardiovascular deaths worldwide were found to be attributable to smoking, accounting for $22 \%$ of total adult cardiovascular deaths in North America and $13 \%$ in western Europe [3]. Moreover, two-thirds of sudden cardiac deaths due to acute coronary thrombosis occur in cigarette smokers [4], and clinical data from the
Dr. Katrin Schaefer

Department of Cardiology and Pulmonary Medicine, University of Göttingen Robert Koch Strasse 40, DE-37099 Göttingen (Germany)

Tel. +49551398927, Fax +495513914131

E-mail katrin.schaefer@med.uni-goettingen.de 
Table 1. Test atmosphere characterization

\begin{tabular}{|c|c|c|c|c|c|c|c|}
\hline & \multicolumn{4}{|c|}{ 1st experiment } & \multicolumn{3}{|c|}{ 2nd experiment } \\
\hline & Sham & MS 600 & MS 1,200 & MS 1,800 & Sham & MS 1,800 & MS 2,400 \\
\hline $\mathrm{TPM}, \mu \mathrm{g} / \mathrm{l}$ & $<\mathrm{dl}$ & $581 \pm 32$ & $587 \pm 27$ & $593 \pm 25$ & $<\mathrm{dl}$ & $600 \pm 31$ & $604 \pm 25$ \\
\hline $\mathrm{CO}, \mathrm{ppm}$ & $<\mathrm{dl}$ & $606 \pm 42$ & $603 \pm 37$ & $601 \pm 35$ & $<\mathrm{dl}$ & $604 \pm 2.2$ & $603 \pm 27$ \\
\hline Nicotine, $\mu g / l$ & $<\mathrm{dl}$ & $37 \pm 5.8$ & $37 \pm 5.8$ & $37 \pm 5.8$ & $<\mathrm{dl}$ & $37 \pm 3.8$ & $37 \pm 3.8$ \\
\hline Formaldehyde, $\mu \mathrm{g} / 1$ & nd & $0.5 \pm 0.05$ & $0.5 \pm 0.05$ & $0.5 \pm 0.05$ & nd & $0.5 \pm 0.09$ & $0.5 \pm 0.09$ \\
\hline Acetaldehyde, $\mu \mathrm{g} / \mathrm{l}$ & nd & $43 \pm 1.5$ & $43 \pm 1.5$ & $43 \pm 0.9$ & nd & $42 \pm 3.7$ & $42 \pm 3.7$ \\
\hline Acrolein, $\mu \mathrm{g} / \mathrm{l}$ & nd & $4.1 \pm 0.2$ & $4.1 \pm 0.2$ & $4.1 \pm 0.2$ & nd & $4.3 \pm 0.3$ & $4.3 \pm 0.3$ \\
\hline
\end{tabular}

nd = Not determined; $<\mathrm{dl}=$ below the detection limit.

Atherosclerosis Risk in Communities (ARIC) study [5] show that smoking is associated with accelerated atherosclerosis progression. Recently, a subanalysis of the Heart Outcomes Prevention Evaluation trial [6] reported a 1.65fold increased relative risk for cardiovascular death in smokers compared to never-smokers. Similarly, the Cancer Prevention Studies revealed an almost 2-fold elevation in death rate from coronary heart disease in current smokers compared to non-smokers [7]. On the other hand, conflicting results have been reported on the association between cigarette smoking and intimal hyperplasia following coronary angioplasty [8-10], and only a few experimental studies have systematically investigated the effect of cigarette smoke exposure on neointima formation using appropriate animal models of endothelial injury [11-14]. There is also a scarcity of longitudinal data on the effects of smoking on vascular homeostasis [11]. Thus, the data supporting the procoagulant and atherogenic consequences of cigarette smoke and its components have so far been obtained mainly by in vitro studies, clinical observations, and the histological analysis of atherectomy and/or autopsy specimens in humans [4, $15]$.

In the present study, we investigated the biological effects of long-term (i.e., over a period of $10 \pm 1$ weeks) exposure to cigarette mainstream smoke (MS) on arterial thrombosis and neointima formation using the established ferric chloride $\left(\mathrm{FeCl}_{3}\right)$ model of vascular injury in the apolipoprotein $\mathrm{E}$ knockout $\left(\mathrm{apoE}^{-/-}\right)$mouse. Moreover, the effect of cigarette smoke extract on smooth muscle cells (SMCs) in culture was investigated. Our findings suggest that cigarette smoke exposure promotes arterial thrombosis and modulates the size and composition of neointimal lesions, possibly by stimulating SMC proliferation.

\section{Methods}

Smoke Generation and Total Particulate Matter Preparation

MS was generated from the Reference Cigarette 2R4F (University of Kentucky, Lexington, Ky., USA). Cigarettes were conditioned and smoked in conformity with ISO standards 3402 [16] and 3308 [17]. MS was generated on a 30-port smoking machine (Type SM85; Borgwaldt CSR, Hamburg, Germany) equipped with a 4-piston pump [18]. In order to achieve the target concentration of $600 \mu \mathrm{g}$ total particulate matter (TPM)/l for the in vivo experiments, MS from 2 smoking machines with active sidestream exhaust was diluted with filtered, conditioned air at the outlet of the smoking machine and conveyed to the exposure chambers through glass tubing.

To monitor the stability and reproducibility of smoke generation, the concentrations of TPM, carbon monoxide (CO), nicotine, and aldehydes, as well as the temperature and relative humidity in the exposure chambers were determined, as previously described $[19,20]$. Samples were collected within the breathing zone of the mice. $\mathrm{CO}$, temperature, and relative humidity were monitored continuously. TPM concentrations were determined gravimetrically at least once per day; nicotine and aldehyde (formaldehyde, acetaldehyde, acrolein) concentrations were determined weekly. The results are shown in table 1 . Temperature and relative humidity in the exposure chambers were within standard limits, i.e. $22 \pm 2{ }^{\circ} \mathrm{C}$ and $30-70 \%$, respectively.

For the in vitro experiments, TPM was prepared according to a previously published method [21]. In brief, MS was generated on a 20-port smoking machine (Borgwaldt) and TPM was trapped on Cambridge fiber filters (Borgwaldt), determined gravimetrically, extracted with dimethyl sulfoxide (DMSO), sterile-filtered, and stored at $-80^{\circ} \mathrm{C}$. Gravimetric determination of TPM yield was as previously described [20].

\section{Animals and Exposure}

Male apoE ${ }^{-/-}$(B6.129P2_Apoe $\mathrm{tm}_{1} \mathrm{Unc}_{11}$; Taconic Europe, Denmark), fed standard rodent chow (Global Rodent Maintenance diet 2014; Harlan Teklad, Bicester, UK), were used in this study. Mice were exposed to filtered, conditioned fresh air (sham; $\mathrm{n}=60$ ) or to MS at a concentration of $600 \mu \mathrm{g}$ TPM/l for $1,2,3$, or $4 \mathrm{~h}$ for a total daily dose of $600 \mu \mathrm{g}$ (MS 600; $\mathrm{n}=20$ ), 1,200 $\mu \mathrm{g}$ (MS $1,200 ; \mathrm{n}=20), 1,800 \mu \mathrm{g}(\mathrm{MS} 1,800 ; \mathrm{n}=58)$, or $2,400 \mu \mathrm{g}$ TPM/1 
(MS 2,400; $\mathrm{n}=23$ ), respectively. Mice were whole-body exposed 5 days a week for a total of $10 \pm 1$ weeks. Beginning at the age of 6-8 weeks, mice were gradually adapted to the exposure procedure by increasing the length of exposure time, starting with $1 \mathrm{~h}$ on day 1 and ending with $4 \mathrm{~h}$ on day 4 . Mice in the MS 1,800 group were exposed in 2 separate experiments $(n=18$ and $n=40)$ with corresponding sham exposure $(n=17$ and $n=43)$.

Care and use of the animals conformed with the Guide for the Use and Care of Laboratory Animals (National Institutes of Health, revised 1996; NIH 85-23). All animal experiments were approved by the institutional animal care and use committee.

\section{Vascular Injury Protocol}

After exposure for $10 \pm 1$ weeks, mice were anaesthetized by intraperitoneal injection of xylazine hydrochloride (CP-Pharma, Burgdorf, Germany) and ketamine hydrochloride (Pharmanovo $\mathrm{GmbH}$, Hannover, Germany), and subjected to carotid artery injury using $10 \%$ ferric chloride as previously described $[22,23]$. Briefly, the left carotid artery was carefully dissected and then injured by placing a $0.5-1.0 \mathrm{~mm}$ strip of filter paper soaked in $10 \%$ ferric chloride solution onto the adventitia for $3 \mathrm{~min}$. Of note: the injured arterial segment appeared macroscopically normal (magnification $\times 10$ ) and free of any atherosclerotic lesions. Carotid blood flow was monitored before injury and $25 \mathrm{~min}$ after injury using an ultrasound flow probe $(0.5 \mathrm{VB})$ interfaced with a flowmeter (model T106; Transonic Systems, Ithaca, N.Y., USA) and a computerized data acquisition program (WinDaq Lite; DATAQ Instruments, Akron, Ohio, USA). Occlusive thrombosis was defined as blood flow $<0.2 \mathrm{ml} / \mathrm{min}$. Following induction of arterial injury and thrombosis at the left carotid artery, inhalation exposure was interrupted for 2 days to allow the animals to recover, then resumed and continued as described above until day 7 or 21 after surgery.

\section{Determination of Lipid Levels}

Blood was obtained at the time of tissue harvest and plasma was prepared for the analysis of triglyceride and total cholesterol levels using commercially available kits from Thermo Clinical Labsystems (Frankfurt, Germany), according to manufacturer recommendations.

\section{Determination of Carboxyhemoglobin Concentrations}

In order to verify MS exposure in vivo, blood samples were collected from the retrobulbar venous plexus under diethyl ether narcosis using heparinized micropipettes. Blood samples for carboxyhemoglobin $(\mathrm{COHb})$ determination were obtained during the last $10 \mathrm{~min}$ of MS exposure. $\mathrm{COHb}$ concentrations were determined according to the gas chromatography method previously described for rats [19].

\section{Morphometric Analysis of Neointima Formation}

Three weeks after injury, mice were anesthetized and carefully perfusion-fixed with $4 \%$ zinc formalin. The injured carotid artery together with the bifurcation was harvested and processed for paraffin embedding. The effect of cigarette smoking on neointima formation was then quantified histochemically on $5 \mu \mathrm{m}$ thick Verhoeff's Elastica-stained cross sections using computerized image analysis software (Image-Pro Plus; Media Cybernetics, Silver Spring, Md., USA), as previously described [23]. Five sections through the injured arterial segment (equally spaced at
$200 \mu \mathrm{m}$ intervals) were evaluated, and the results were averaged for each animal ( $\mathrm{n}=16-20$ per group).

\section{Immunohistochemical Analysis of Lesion Composition}

Paraffin sections of carotid arteries at 3 weeks after arterial injury were analyzed for the presence of $\alpha$-actin-positive or myosin heavy chain-positive SMCs, and for fibrin/fibrinogen [23, 24]. In particular, the presence of SMCs was assessed using a monoclonal anti-mouse $\alpha$-actin antibody (peroxidase-labeled and prediluted; Dako, Hamburg, Germany), followed by incubation with aminoethyl carbazole reagent (Zytomed, Berlin, Germany). For the detection of myosin heavy chain-positive SMCs, a monoclonal mouse anti-human antibody (dilution 1:20; Dako) was used in conjunction with the mouse-on-mouse (M.O.M.) blocking agent (Vector Laboratories, Burlingame, Calif., USA). Immunohistochemistry for fibrin/fibrinogen was performed using a polyclonal rabbit anti-human antibody (dilution 1:200; Dako). Proliferating cells were detected using anti-proliferating cell nuclear antigen (PCNA) antibody (prediluted; Zytomed). Apoptotic cells were determined using the In situ Cell Death Detection kit (Roche Diagnostics, Mannheim, Germany) and the TUNEL (Terminal Desoxyribosyl-Transferase mediated dUTP Nick End Labeling) technique. The number of PCNA-positive or TUNELpositive cells was expressed as a percentage of the total cell nuclei within the vessel wall (i.e. the area within the external elastic layer). The amount of $\alpha$-actin-positive, myosin heavy chain-positive, or fibrin/fibrinogen-immunopositive material within the vessel wall was quantified using Image-Pro image analysis software (Media Cybernetics).

\section{Culture and Analysis of Vascular Smooth Muscle Cells}

Human aortic SMCs (a kind gift from Drs. M. Hecker and T. Korff, Heidelberg, Germany) were maintained in a mixture (1:1:1) of SMC growth medium (PromoCell, Heidelberg, Germany), Waymouth MB752/1 medium (Invitrogen, Karlsruhe, Germany), and Dulbecco's Modified Eagles medium (Invitrogen). Cells (between passage 3 and 5) were treated with TPM for $24 \mathrm{~h}$ diluted in DMSO at final concentrations ranging from 10 to $500 \mu \mathrm{g}$ TPM/ $\mathrm{ml}$. Controls were treated with an equal volume of DMSO alone. The effect of TPM on cellular apoptosis was determined by flow cytometry using the Annexin V-FITC apoptosis detection kit in conjunction with the vital dye propidium iodide (BD Pharmingen, Heidelberg, Germany). Camptothecin-treated cells were used as positive controls.

To visualize proliferating cells, 5-bromo-2'-deoxyuridine (BrdU; $0.02 \mathrm{mM}$; Serva, Heidelberg, Germany) was added to the cell culture medium $5 \mathrm{~h}$ prior to staining with monoclonal mouse anti-BrdU antibody (dilution 1:100; Dako) and anti-mouse Alexa Fluor 555 IgG secondary antibody (dilution 1:200; Molecular Probes). Cell nuclei were counterstained with 4',6-diamidino-2phenylindole dihydrochloride (DAPI; dilution 1:100; Sigma, Taufkirchen, Germany). The number of BrdU-positive cells was determined in 4 representative microscope fields, in duplicate, and expressed as percentage of total (i.e. DAPI-positive cells).

\section{Statistical Analysis}

Data are presented as mean \pm SEM, unless stated otherwise. Differences between 2 groups were compared using the Student's $t$ test for unpaired means. If more than 2 groups were compared, either the One-Way Analysis of Variance (ANOVA) was per- 
Table 2. Body weight and plasma lipid levels at time of tissue harvest

\begin{tabular}{llccccc}
\hline Group & $\begin{array}{l}\text { Body weight } \\
\mathrm{g}\end{array}$ & p value & $\begin{array}{l}\text { Cholesterol } \\
\mathrm{mmol} / \mathrm{l}\end{array}$ & $\mathrm{p}$ value & $\begin{array}{l}\text { Triglycerides } \\
\mathrm{mmol} / \mathrm{l}\end{array}$ & $\mathrm{p}$ value \\
\hline Sham & $30.1 \pm 0.3$ & - & $9.8 \pm 0.5$ & - & $1.4 \pm 0.1$ & - \\
MS 600 & $29.1 \pm 0.5$ & $\mathrm{~ns}$ & $12.0 \pm 0.6$ & $<0.05$ & $1.4 \pm 0.1$ & $\mathrm{~ns}$ \\
MS 1,200 & $30.1 \pm 0.4$ & $\mathrm{~ns}$ & $11.4 \pm 0.8$ & $\mathrm{~ns}$ & $1.3 \pm 0.1$ & $\mathrm{~ns}$ \\
MS 1,800 & $26.8 \pm 0.3$ & $<0.01$ & $12.0 \pm 0.3$ & $<0.01$ & $1.4 \pm 0.1$ & $\mathrm{~ns}$ \\
MS 2,400 & $25.3 \pm 0.5$ & $<0.01$ & $13.7 \pm 0.9$ & $<0.01$ & $1.5 \pm 0.1$ & $\mathrm{~ns}$ \\
\hline
\end{tabular}

All $\mathrm{p}$ values are difference between experimental group and sham. $\mathrm{ns}=$ Not significant.

Table 3. Thrombotic occlusion in response to $\mathrm{FeCl}_{3}$ injury

\begin{tabular}{lcccc}
\hline Group & $\begin{array}{l}\text { Median time to } \\
\text { occlusion, min }\end{array}$ & p value & $\begin{array}{l}\text { Occluded } \\
\text { vessels, \% }\end{array}$ & p value \\
\hline Sham & 14.9 & - & 75 & - \\
MS 600 & 13.0 & 0.138 & 85 & 0.538 \\
MS 1,200 & 13.9 & 0.122 & 85 & 0.538 \\
MS 1,800 & 9.7 & $<0.001$ & 93 & 0.015 \\
MS 2,400 & 8.0 & $<0.001$ & 100 & 0.008 \\
\hline
\end{tabular}
sham.

All $\mathrm{p}$ values are difference between experimental group and

formed followed by Dunnett's multiple comparison test (for parametric values), or the Kruskal-Wallis test was performed followed by Dunn's multiple comparison test (for non-parametric values). For comparison of categorical parameters (thrombotic occlusion, recanalization), Fisher's Exact test or $\chi^{2}$ analysis (for observations $>100$ ) were employed. $\mathrm{p}<0.05$ was considered significant. All statistical analyses were performed using GraphPad PRISM data analysis software (v. 4.01; GraphPad Software, Inc, San Diego, Calif., USA).

\section{Results}

In order to study the effects of cigarette smoke exposure on the thrombogenicity of mouse vessels and the formation of neointimal lesions in response to vascular injury, apoE $\mathrm{E}^{-/-}$mice were exposed to cigarette mainstream smoke (MS) over a period of $10 \pm 1$ weeks. Different dosages of MS were tested by increasing the length of exposure (ranging from 1 to $4 \mathrm{~h}$ per day).

Determination of plasma carboxyhemoglobin levels $(\mathrm{COHb})$ revealed significantly increased concentrations in the MS 1,800 group ( $48 \pm 2.8 \%$; $n=6$ ), thus confirming effective inhalation of $\mathrm{MS}$; $\mathrm{COHb}$ levels were below

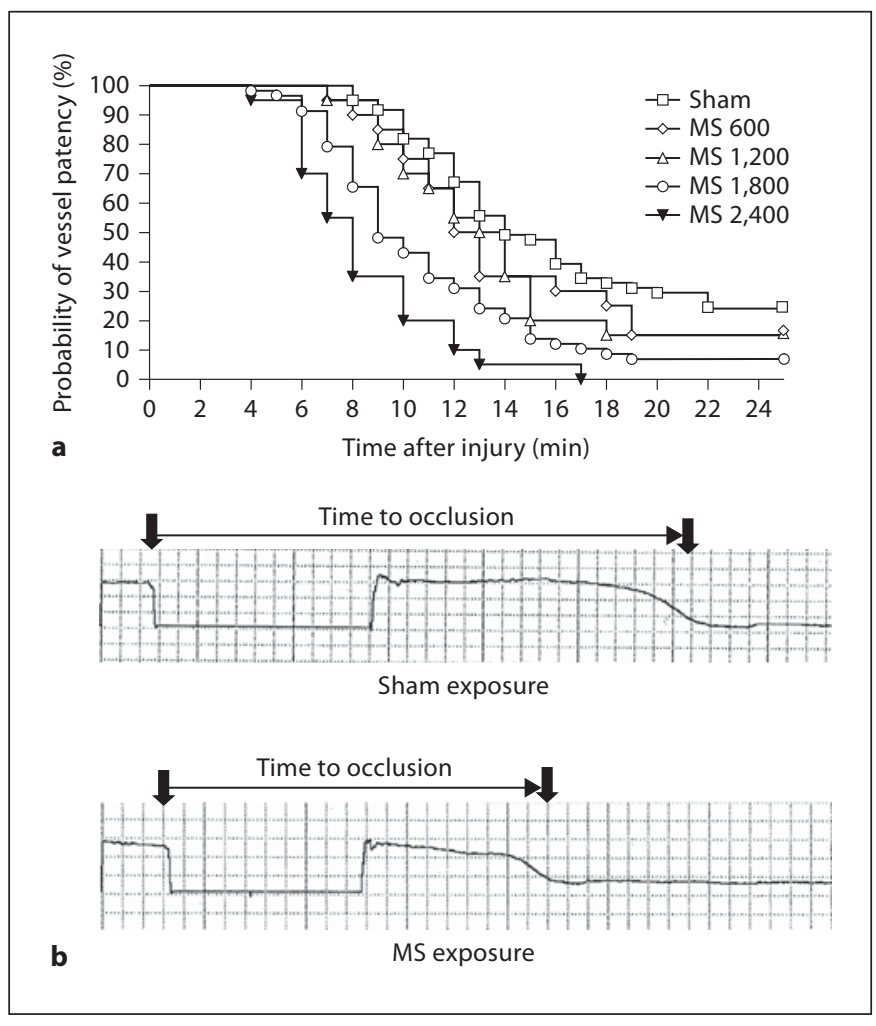

Fig. 1. Thrombotic occlusion after ferric chloride-induced vascular injury. a Vascular patency rates over time after arterial injury. b Representative flow curves showing the thrombotic response in sham-exposed and MS-exposed mice.

the detection limit in sham mice $(n=6)$. At the end of the $10 \pm 1$ week-exposure period, a significant reduction in body weight was observed in the MS 1,800 and MS 2,400 groups (table 2). MS exposure was also associated with significantly increased plasma total cholesterol levels in the MS 600 , MS 1,800, and MS 2,400 groups, while plasma triglyeride levels remained unchanged. 
Cigarette Smoke Exposure Shortens the Time to

Thrombosis and Reduces Vascular Patency Rates

In order to study the effect of cigarette smoke exposure on the formation of platelet-rich thrombi, carotid artery injury was induced using $10 \%$ ferric chloride as previously described [22, 23]. Mean baseline carotid blood flow before the induction of arterial injury was similar in all groups, ranging from $0.49 \pm 0.09 \mathrm{ml} / \mathrm{min}$ in the sham group to $0.40 \pm 0.09 \mathrm{ml} / \mathrm{min}$ in MS 2,400 group. No significant effects were seen in response to arterial injury in the MS 600 or MS 1,200 groups (tables 2 and 3, fig. 1). In contrast, the time to thrombotic occlusion was significantly shortened in the MS 1,800 and MS 2,400 groups compared to sham (fig. 1a, table 3). For example, the median time to thrombotic occlusion was reduced from 14.9 min in the sham group to $9.7 \mathrm{~min}$ in the MS 1,800 group and to $8.0 \mathrm{~min}$ in the MS 2,400 group. Moreover, the proportion of mice that developed occlusive thrombosis after vascular injury was significantly increased in the MS
1,800 and MS 2,400 groups (table 3). Accordingly, mice in these groups exhibited significantly lower patency rates at the end of the 25 min observation period after injury. The effects of MS exposure on the vascular response to injury are also reflected by the Doppler blood flow curves, indicating thrombosis and fibrinolysis over the first $25 \mathrm{~min}$ after the induction of vascular injury (representative findings are shown in fig. 1b). Thus, MS exposure for $10 \pm 1$ weeks prior to vascular injury appeared to promote the formation and stabilization of arterial thrombi, and this effect appeared to be dose dependent, reaching statistical significance after mice were exposed for 3 or more hours per day (MS 1,800 and MS $2,400)$.

One week after injury, the vascular lumen was still partly occluded by thrombotic material, as determined histologically. However, morphometric analysis of VESstained cross sections revealed no differences between sham mice and mice in the MS 1,800 group with regard

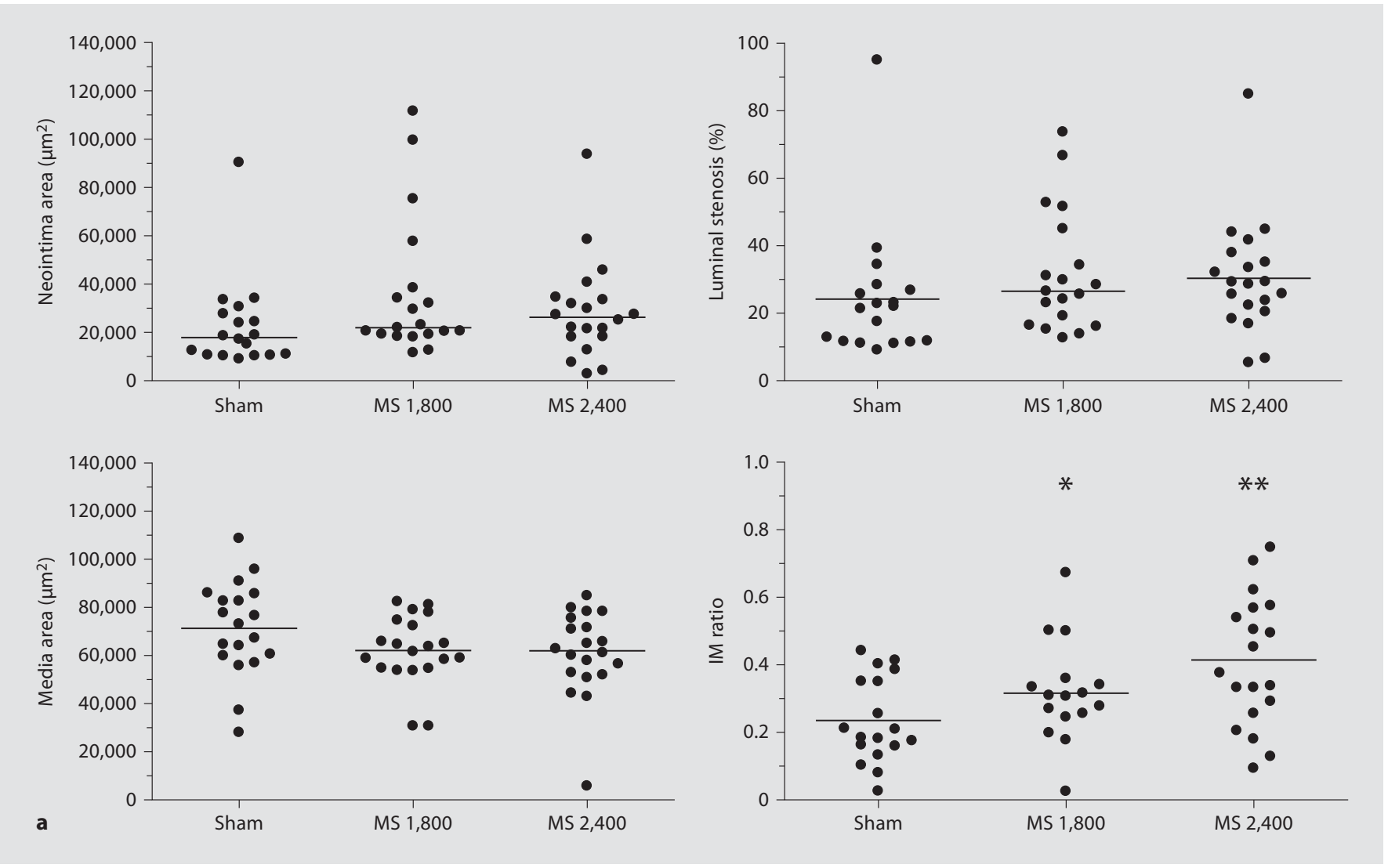

Fig. 2. Neointima formation 3 weeks after injury. a Morphometric analysis of VES-stained cross sections through the injured carotid artery (individual values are shown). Horizontal lines through each grouping represent the median in each exposure group. ${ }^{*} \mathrm{p}<0.05,{ }^{* *} \mathrm{p}<0.01$. 

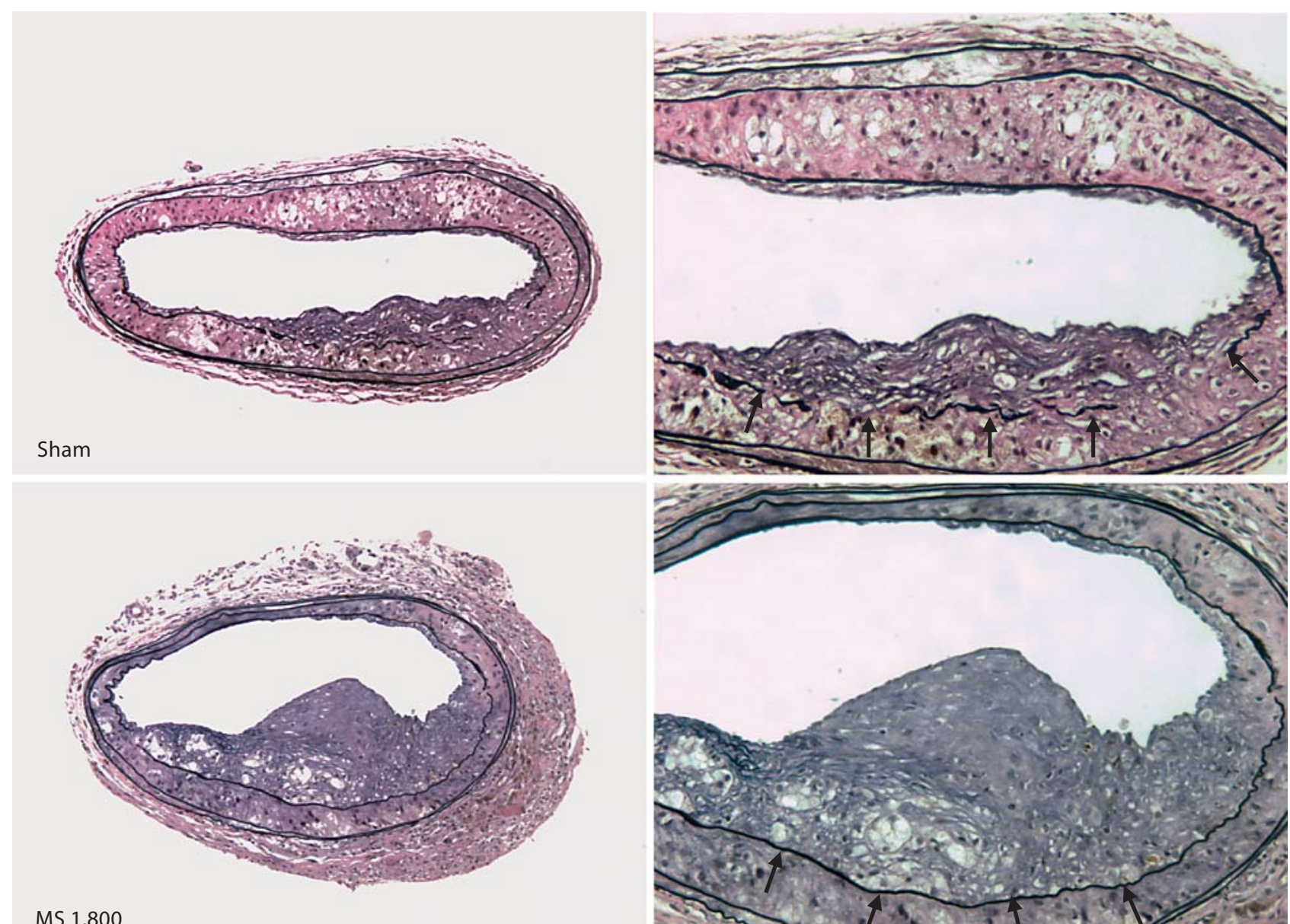

MS 1,800

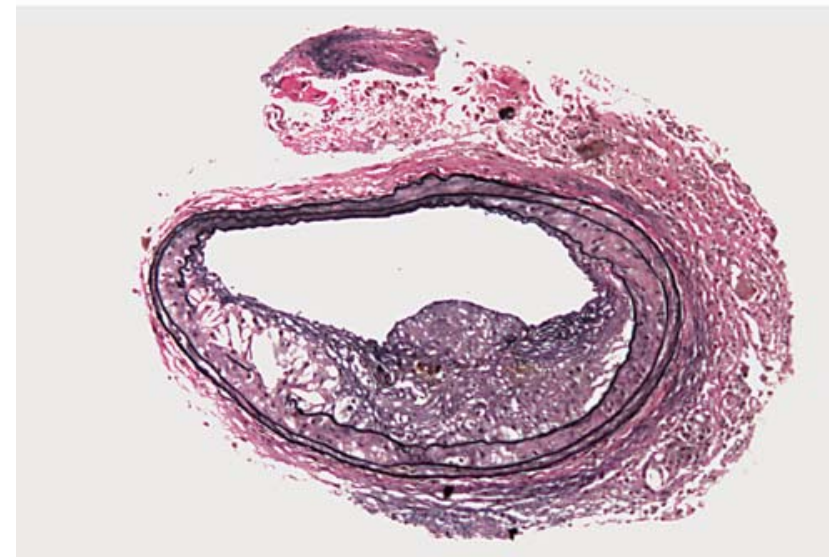

MS 2,400
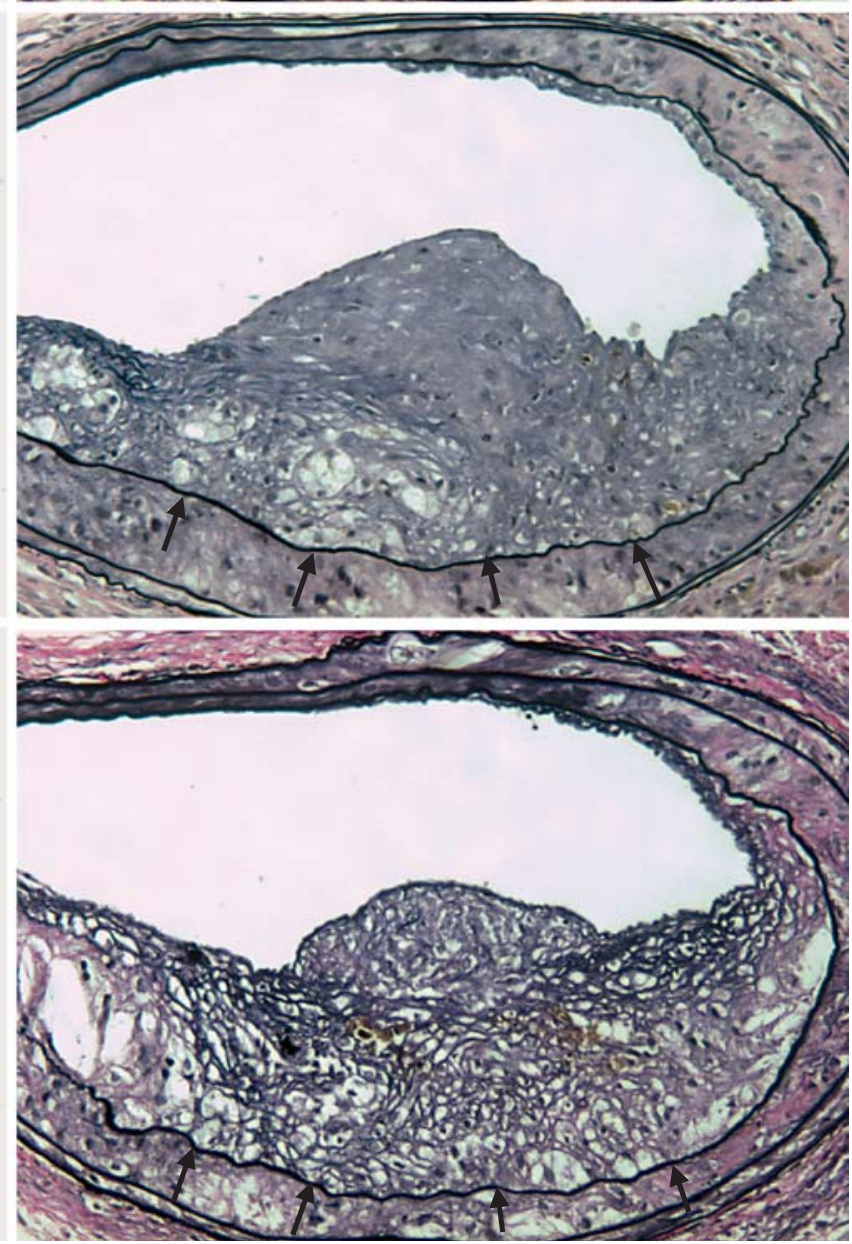

b

Fig. 2. Neointima formation 3 weeks after injury. b Representative sections through the injured carotid artery segment 3 weeks after injury. Magnification: $\times 100$ (left panels) and $\times 200$ (right panels). Arrows point to the internal elastic lamina. 

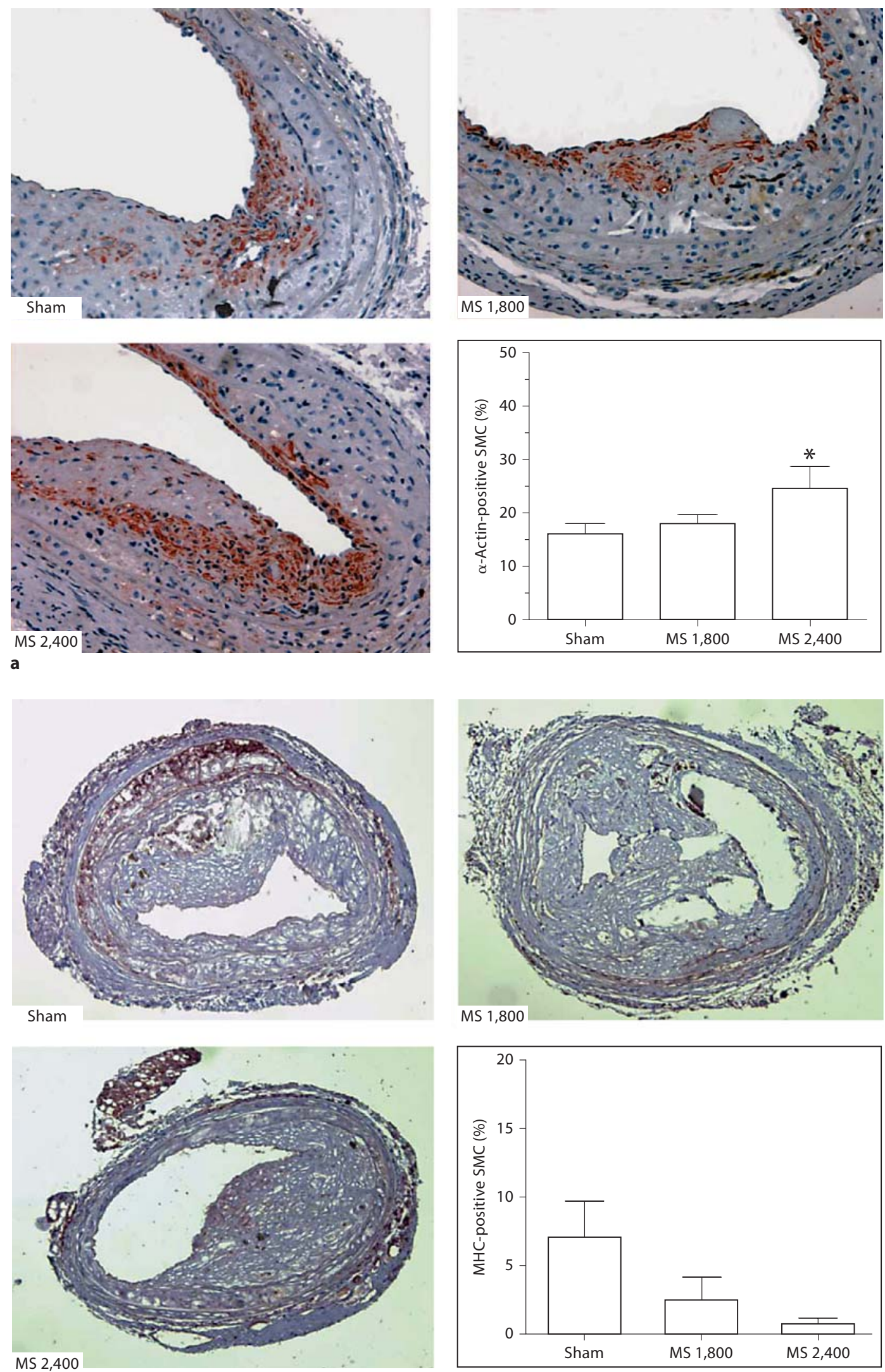

b 
to both the size of the intraluminal thrombotic material $\left(35,672 \pm 4,627 \mu \mathrm{m}^{2}\right.$ cross-sectional area in sham vs. $37,591 \pm 3,793 \mu \mathrm{m}^{2}$ in the MS 1,800) and the degree of the resulting luminal stenosis $(54 \pm 6.2 \%$ in sham vs. 51 $\pm 5.0 \%$ in MS 1,800 ). Also, the amount of immunopositive fibrin/fibrinogen was similar $(47 \pm 4.7 \%$ in sham vs. $45 \pm 4.5 \%$ in MS 1,800). Mice in the other MS groups were not examined at this time point.

\section{Effect of Cigarette Smoke Exposure on Neointima \\ Formation after Vascular Injury}

In the second part of the study, the effects of 2 different doses of cigarette smoke (i.e. MS 1,800 and MS 2,400) on neointima formation were investigated. Three weeks after injury, the intraluminal thrombotic material had been completely resolved and the lumen was now (partly) occluded by a cell-rich neointima. As shown in figure 2, systematic morphometric analysis revealed that mice in the MS 1,800 and MS 2,400 groups tended to show enhanced neointima area $\left(17,919 \mu \mathrm{m}^{2}\right.$ in sham, $21,937 \mu \mathrm{m}^{2}$ in MS 1,800 and 26,298 $\mu \mathrm{m}^{2}$ in MS 2,400), and the degree of luminal stenosis increased (22\% in sham, $27 \%$ in MS 1,800 and $29 \%$ in MS 2,400); however, the differences did not reach statistical significance. Overall, the median intima-to-media ratio was significantly increased [0.197 in sham, 0.316 in MS $1,800(\mathrm{p}=0.026)$ and 0.414 in MS 2,400 $(\mathrm{p}=0.006)]$.

\section{Effect of Cigarette Smoke Exposure on the Cellular Composition of Vascular Lesions}

Next, the effects of MS on SMCs, the predominant cell type within neointimal lesions, were analyzed. The amount of neointimal $\alpha$-actin-positive vascular SMCs was significantly increased in the MS 2,400 group (16 \pm $1.9 \%$ in sham, $18 \pm 1.6 \%$ in MS 1,800 and $25 \pm 4.2 \%$ in MS 2,400; fig. 3a). There was also a trend towards a higher percentage of PCNA-positive (i.e. proliferating) cells within the vessel wall after exposure of $\mathrm{apoE}^{-/-}$mice to MS (41 $\pm 7.5 \%$ of total cells in sham vs. $65 \pm 6.8 \%$ in MS 1,800 and $57 \pm 6.8 \%$ in MS 2,400; fig. 4a). Moreover, 9.2 $\pm 2.5 \%$ of TUNEL-positive (i.e. apoptotic) cells were detected in the sham group compared to $5.0 \pm 1.2 \%$ in the MS 1,800 group and $6.7 \pm 1.1 \%$ in the MS 2,400 group

Fig. 3. Effect of MS exposure on the amount of SMC within vascular lesions. a Immunohistochemical detection of $\alpha$-actin-positive SMC within the vascular wall 3 weeks after injury (red signal; $\mathrm{n} \geq 10$ mice per group). $\mathbf{b}$ Immunohistochemical detection of myosin heavy chain-positive SMC (brown signal; $\mathrm{n}=5$ mice per group). ${ }^{*} \mathrm{p}<0.05$.

Cigarette Smoke and Vascular Lesions in Mice (fig. 4b). Because SMC proliferation goes along with phenotypic modulation as well as de-differentiation, the presence of myosin heavy chain-positive cells (i.e. differentiated SMC), was also analyzed. A trend towards a dose-dependent reduction was observed in MS-exposed mice $(7.0 \pm 2.6 \%$ in sham, $2.5 \pm 1.7 \%$ in MS 1,800 and $0.7 \pm 0.4 \%$ in MS 2,400; fig. 3b); however, the differences did not reach statistical significance.

In vitro, treatment of cultured SMC with $10 \mu \mathrm{g}$ TPM/ $\mathrm{ml}$ significantly enhanced the percentage of BrdU-positive (i.e. proliferating) cells compared to DMSO alone (14 $\pm 1.3 \%$ in TPM-treated cells vs. $10 \pm 1.2 \%$ in DMSOtreated cells; fig. 5), without significantly affecting cellular viability (fig. 6a), apoptosis (fig. 6b), or necrosis (fig. 6c). However, SMC proliferation was significantly reduced or even completely inhibited after stimulation with higher dosages of TPM (50 and $100 \mu \mathrm{g} / \mathrm{ml}$; fig. 5). Moreover, flow cytometry analysis revealed that treatment of SMC with $100 \mu \mathrm{g}$ TPM/ml significantly reduced the percentage of viable cells (fig. 6a) and increased in the percentage of apoptotic cells (fig. 6b). Finally, treatment with $500 \mu \mathrm{g} \mathrm{TPM} / \mathrm{ml}$ resulted in a significant increase in the amount of necrotic (i.e. annexin V-positive, PI-positive) cells (fig. 6c).

\section{Discussion}

Cardiovascular disease and its thrombotic complications, particularly myocardial infarction and stroke, are the principal causes of death in the United States and Europe. Cigarette smoking is a well established risk factor for the development and progression of atherosclerosis $[2,5,25]$, and histopathological analysis of human coronary plaques has found that smoking predicts the severity of intimal hyperplasia and atherosclerosis $[4,15]$. Similarly, experimental studies using the apoE ${ }^{-/-}$mouse model [26, 27], the LDL receptor knockout mouse model [28] and cholesterol-fed rabbits [29] revealed that exposure to cigarette smoke and nicotine increases the size of spontaneous atherosclerotic lesions.

In contrast, the association between cigarette smoking and intimal hyperplasia in response to vascular injury is less clear, and clinical studies have reported conflicting results regarding the association between smoking and the outcome following coronary angioplasty. For example, continued smoking has been shown to increase the risk of adverse cardiac events after percutaneous coronary interventions [9] and to increase the rate of restenosis [8]. Other studies, however, have shown that neither a history

J Vasc Res 2008;45:480-492 

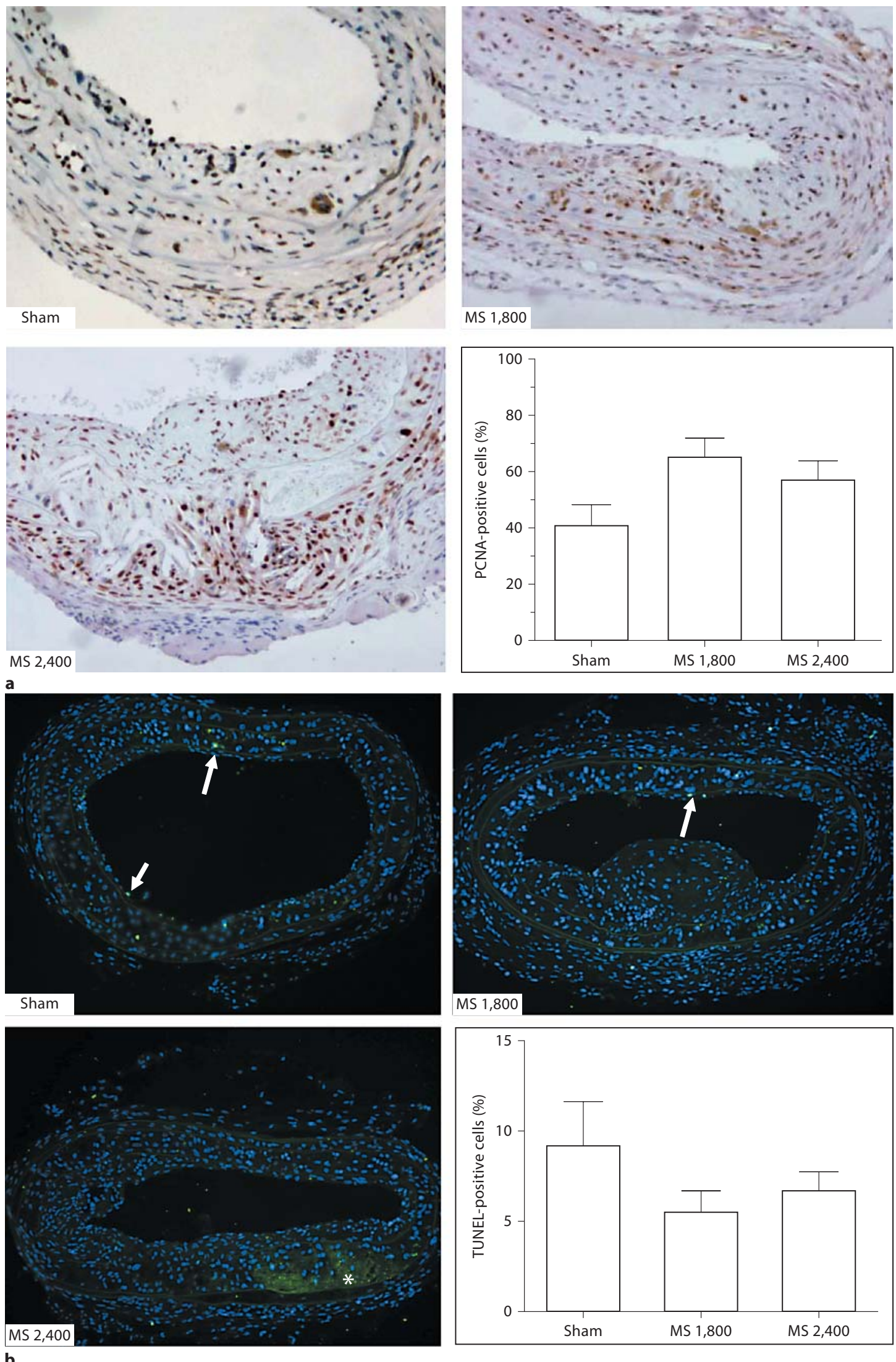

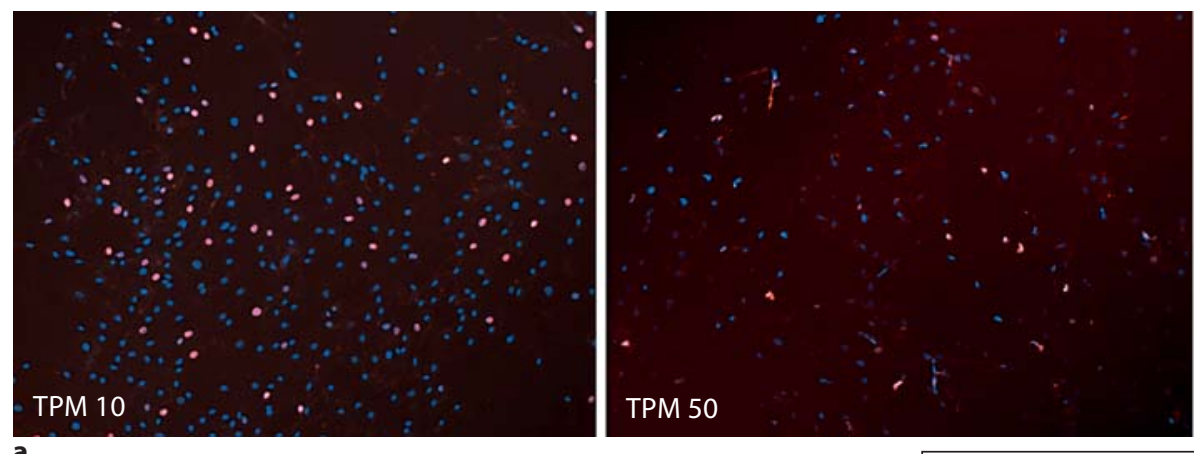
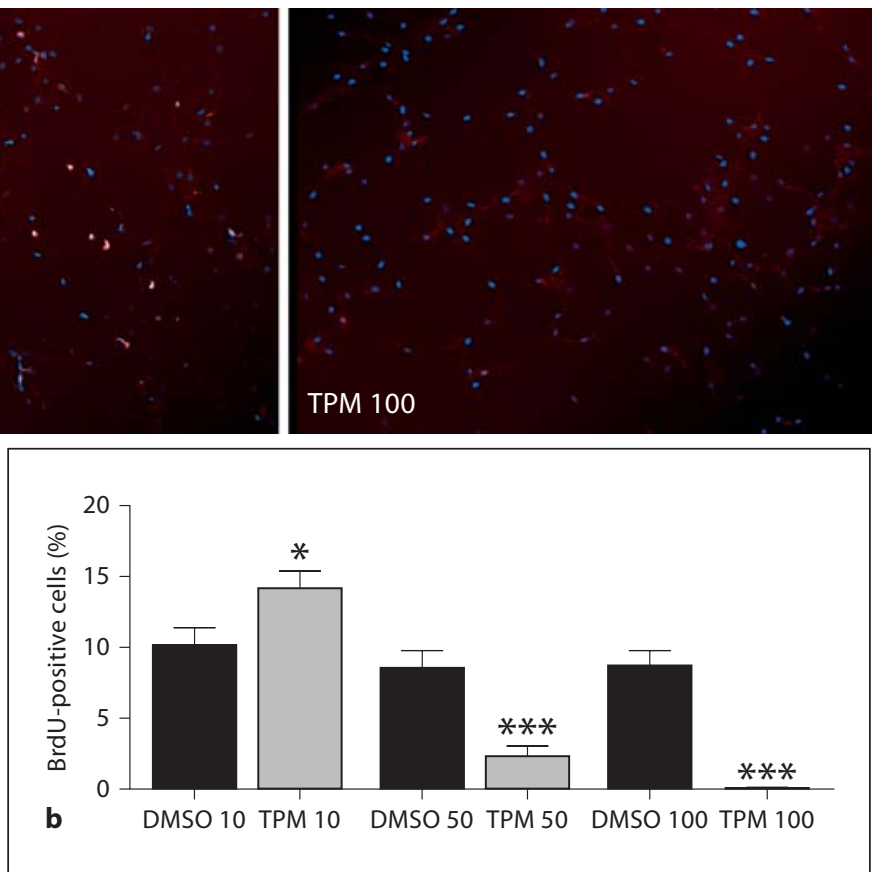

Fig. 5. Effect of TPM on the proliferation of SMC in vitro. a Immunofluorescence detection of BrdU-positive cells (i.e. proliferating cells; red signal). Cell nuclei were counterstained with DAPI (blue signal). b Quantitative analysis of 3 independent experiments. ${ }^{*} \mathrm{p}<0.05,{ }^{* *} \mathrm{p}<0.001$.

of smoking [10, 30] nor continued smoking [31] were risk factors for restenosis after percutaneous transluminal coronary angioplasty $[32,33]$. Some studies even reported that smokers required less frequent revascularization [9] or had reduced restenosis rates [32, 34, 35], and the existence of a 'smokers' paradox' has been postulated.

The lack of clinical and experimental evidence to support a specific association between cigarette smoking and restenosis might, at least in part, be due to a lack of appropriate animal models to study the effects of cigarette smoking in vivo. The majority of studies so far have been performed exclusively on cultivated cells, which might behave differently from those residing inside lesions. Single components of the extremely heterogenous aerosol called 'cigarette smoke' have also been studied [36-38].

Only a few studies are available that deal with the effects of whole-body exposure to cigarette smoke on the cardiovascular system, and in particular on neointima formation following experimental vascular injury. For example, inhalation of 1 cigarette per day over 5 weeks

Fig. 4. Effect of MS exposure on cellular proliferation and apoptosis within the neointima. a Immunohistochemical determination of PCNA-positive cells (i.e. proliferating cells; dark brown signal). b Immunohistochemical determination of TUNEL-positive cells (i.e. apoptotic cells; green signal; arrows). Asterisk indicates acellular region. Magnification: $\times 200$.

Cigarette Smoke and Vascular Lesions in Mice significantly enhanced intima hyperplasia after carotid arterial cuffing, both in apoE $\mathrm{E}^{-/-}$mice fed Western chow [14] and wild-type mice fed a standard diet [11]. Similarly, cigarette smoke exposure (8 cigarettes per day) for 2 weeks before and after carotid endarterectomy has been reported to increase intimal hyperplasia in rats [12]. In the present study, we demonstrate the feasibility of combining MS exposure with ferric chloride-induced vascular injury. Moreover, we analyzed the long-term $(10 \pm 1$ weeks) effects of MS exposure on both arterial thrombosis and neointima formation in $\mathrm{apoE}^{-/-}$mice.

Platelet activation and thrombosis at the site of vascular injury or atheromatous plaque rupture play a crucial role in the pathophysiology of acute coronary events. However, no study has so far investigated the effect of long-term MS exposure on arterial thrombosis in vivo. We used the vascular injury model to address the thrombotic properties of blood in response to an injured endothelium. Our results suggest that mice exposed to MS are more prone to develop thrombosis, have shortened time to thrombotic occlusion and develop more stable thrombi at the site of arterial injury. Interestingly, these effects appear to be dose dependent and reached statistical significance after daily exposure of mice to a TPM concentration of $600 \mu \mathrm{g} / \mathrm{l}$ for 3-4 h. Potential pathomechanisms by which MS may promote arterial thrombosis include platelet activation $[39,40]$ and enhanced platelet aggre-

J Vasc Res 2008;45:480-492 
Fig. 6. Effect of TPM on the apoptosis of SMC in vitro. Quantitative FACS analysis of 3 independent experiments. a Viable cells (annexin V-negative and PI-negative). b Apoptotic cells (annexin V-positive, PI-negative). c Dead cells (annexin Vpositive and PI-positive). ${ }^{*} \mathrm{p}<0.05,{ }^{* *} \mathrm{p}<$ $0.01,{ }^{* *} \mathrm{p}<0.001$.

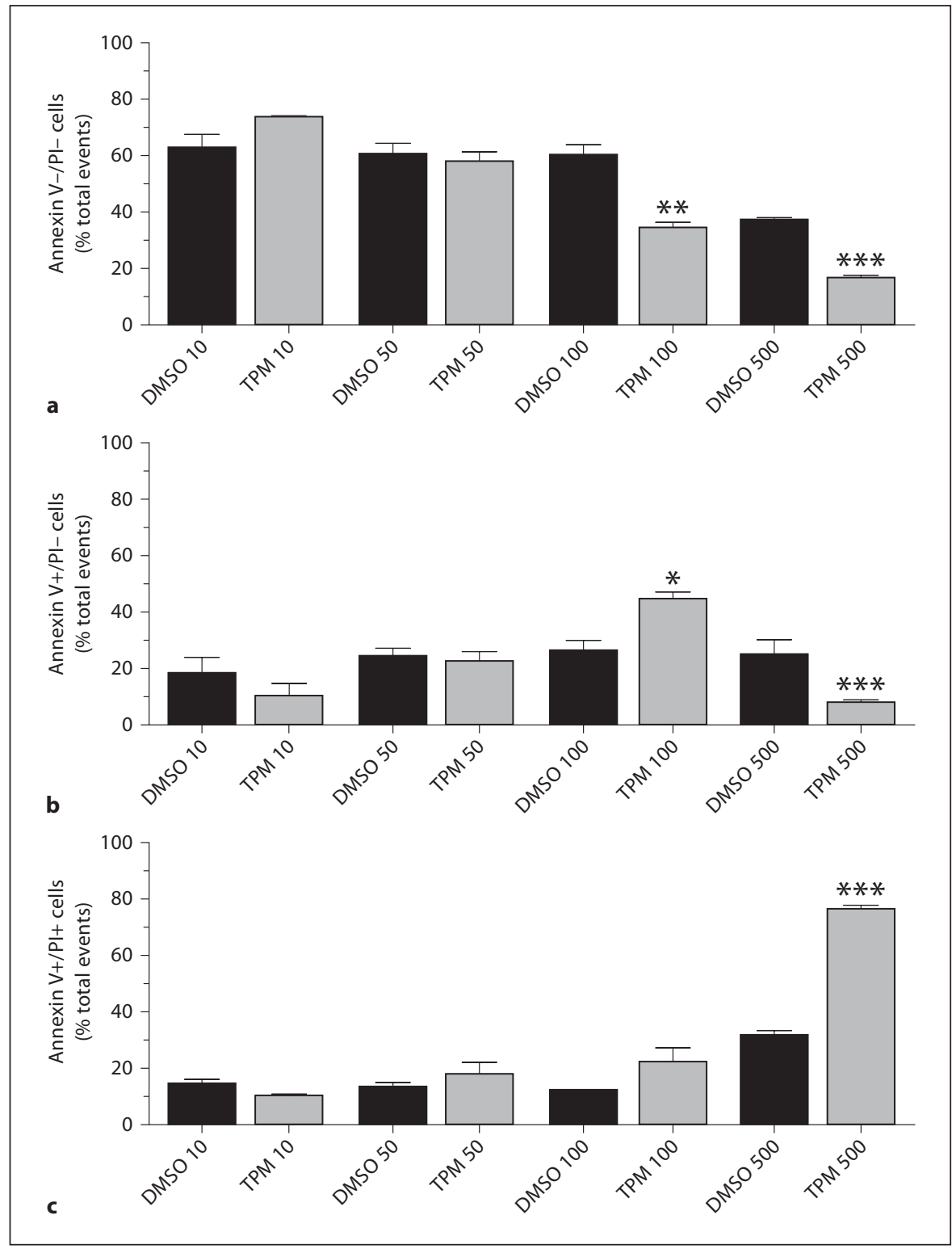

gability [41, 42]. Moreover, cigarette smoking has been associated with elevated levels of blood coagulation markers [43, 44], and enhanced tissue factor expression in atherosclerotic lesions may also contribute to plaque thrombogenicity [45]. On the other hand, impaired fibrinolysis may play a role in the hypercoaguable state found in the cigarette smoke-exposed animals, since elevated plasma levels of plasminogen activator inhibitor-1 were reported in smokers and appeared to correlate with the estimated pack-years of cigarettes smoked [46]. Thus, multiple pathways may be involved in the prothrombotic effects of cigarette smoke exposure.
In addition to the release of growth-promoting factors (such as thrombin or PDGF) from activated platelets, fibrin may serve as a provisional matrix for invading cells. The enhanced thrombotic response observed in the MS 1,800 and MS 2,400 groups may thus have influenced, at least in part, the extent of neointima formation. On the other hand, no differences in the extent of intraluminal thrombotic or fibrin-immunopositive material 7 days after induction of injury were detected between the control and MS 1,800 groups.

Migration and proliferation of SMCs in response to endothelial denudation are thought to be major patho- 
mechanisms underlying the progression of intimal hyperplasia. In the present study, we found that vascular lesions in mice exposed to MS (1,800 and 2,400 $\mu \mathrm{g}$ TPM per day) exhibited an increased intima-to-media ratio compared to sham animals, and were characterized by a significantly higher content of $\alpha$-actin-positive SMCs. Anazawa et al. recently reported that in wild-type mice, cigarette smoke exposure increased cell proliferation and the size of intimal lesions after placement of a cuff around the carotid artery [11]. Also, nicotine has been demonstrated to promote SMC proliferation and migration in atherosclerotic lesions [36, 37]. Proliferation of vascular SMCs goes along with phenotypic modulation from a quiescent and differentiated 'contractile phenotype' towards a 'synthetic phenotype'. We observed a dose-dependent reduction of myosin heavy chain-immunopositive (i.e. differentiated) SMCs in response to MS exposure, although the effects failed to reach statistical significance. In vitro, the effect of TPM on cell proliferation appeared to depend on the dosage used: it was stimulatory at lower concentrations $(10 \mu \mathrm{g} / \mathrm{ml})$ and inhibitory at higher concentrations (50 or $100 \mu \mathrm{g} / \mathrm{ml}$ ). These findings might explain - in addition to differences in the cell lines, exposure times, and preparations used - why some studies reported stimulation of cell proliferation while others reported its inhibition. In addition, they may also be the underlying cause for dose-dependent effects of cigarette smoke exposure on intimal hyperplasia reported after balloon injury in rats [13].

Experimental evidence indicates that attenuation of programmed cell death (apoptosis) is another important determinant of tissue cellularity and intimal thickening [47]. Interestingly, the number of apoptotic cells within the vascular lesions did not differ between the exposure groups, suggesting that up-regulation of cell proliferation may have been more important for the development of intimal hyperplasia in our in vivo model. On the other hand, treatment of SMCs in culture with TPM followed by flow cytometry analysis of annexin $\mathrm{V}$ staining and propidium iodide uptake confirmed previous studies in various other cell lines by demonstrating a dose-dependent increase in the cytotoxicity of TPM. As mentioned above, lower concentrations of TPM in vitro resulted in increased SMC proliferation, but were not sufficient to induce apoptosis, suggesting that these higher (cytotoxic) TPM concentrations might not have been achieved in vivo.

In conclusion, our results suggest that cigarette mainstream smoke exposure promotes arterial thrombosis and modulates the size and composition of neointimal lesions after arterial injury in the $\mathrm{apoE}^{-/-}$mouse model. The dose-dependent effects of cigarette MS on SMC proliferation and apoptosis in vitro may provide an explanation for the conflicting effects reported in the literature and the partly unexpected findings in our in vivo study.

\section{Acknowledgments}

The authors would like to thank Christina Bajraktari, Renate Janssens, Nadja Dever, Kristel Deroover, Sarah Henkel and Stephanie Minne for expert technical assistance. The authors would also like to thank Lynda Conroy for editing the manuscript.

\section{References}

$\nabla_{1}$ Willett WC, Green A, Stampfer MJ, Speizer FE, Colditz GA, Rosner B, Monson RR, Stason W, Hennekens CH: Relative and absolute excess risks of coronary heart disease among women who smoke cigarettes. N Engl J Med 1987;317:1303-1309.

-2 Wolf PA, D’Agostino RB, Kannel WB, Bonita R, Belanger AJ: Cigarette smoking as a risk factor for stroke. The Framingham Study. JAMA 1988;259:1025-1029.

3 Ezzati M, Henley S, Thun MJ, Lopez AD Role of smoking in global and regional cardiovascular mortality. Circulation 2005;112: 489-497.

4 Burke AP, Farb A, Malcom GT, Liang YH, Smialek J, Virmani R: Coronary risk factors and plaque morphology in men with coronary disease who died suddenly. $\mathrm{N}$ Engl J Med 1997;336:1276-1282.

Cigarette Smoke and Vascular Lesions in Mice
5 Howard G, Wagenknecht LE, Burke GL, Diez-Roux A, Evans GW, McGovern P, Nieto FJ, Tell GS: Cigarette smoking and progression of atherosclerosis: the Atherosclerosis Risk in Communities (ARIC) Study. JAMA 1998;279:119-124.

6 Dagenais GR, Yi Q, Lonn E, Sleight P, Ostergren J, Yusuf S; HOPE Trial Investigators: Impact of cigarette smoking in high-risk patients participating in a clinical trial. A substudy from the Heart Outcomes Prevention Evaluation (HOPE) trial. Eur J Cardiovasc Prev Rehabil 2005;12:75-81.

$\checkmark 7$ Thun MJ, Day-Lally CA, Calle EE, Flanders WD, Heath CW: Excess mortality among cigarette smokers: changes in a 20-year interval. Am J Public Health 1995;85:1223-1230.

${ }_{8}$ Galan KM, Deligonul U, Kern MJ, Chaitman BR, Vandormael MG: Increased frequency of restenosis in patients continuing to smoke cigarettes after percutaneous transluminal coronary angioplasty. Am J Cardiol 1988;61: 260-263.

$\checkmark 9$ Hasdai D, Garratt KN, Grill DE, Lerman A, Holmes DR Jr: Effect of smoking status on the long-term outcome after successful percutaneous coronary revascularization. N Engl J Med 1997;336:755-761.

10 Macdonald RG, Henderson MA, Hirshfeld JW Jr, Goldberg SH, Bass T, Vetrovec G, Cowley M, Taussig A, Whitworth H, Margolis JR, et al: Patient-related variables and restenosis after percutaneous transluminal coronary angioplasty: a report from the MHEART Group. Am J Cardiol 1990;66:926931.

11 Anazawa T, Dimayuga PC, Li H, Tani S, Bradfield J, Chyu KY, Kaul S, Shah PK, Cer- 
cek B: Effect of exposure to cigarette smoke on carotid artery intimal thickening: the role of inducible NO synthase. Arterioscler Thromb Vasc Biol 2004;24:1652-1658.

12 Davis JA, Brown AT, Chen H, Wang Y, Poirier LA, Eidt JF, Cruz CP, Moursi MM: Cigarette smoke increases intimal hyperplasia and homocysteine in a rat carotid endarterectomy. J Surg Res 2004;121:69-75.

13 Petrik PV, Gelabert HA, Moore WS, Quinones-Baldrich W, Law MM: Cigarette smoking accelerates carotid artery intimal hyperplasia in a dose-dependent manner. Stroke 1995;26:1409-1414.

-14 Tani S, Dimayuga PC, Anazawa T, Chyu KY, Li H, Shah PK, Cercek B: Aberrant antibody responses to oxidized LDL and increased intimal thickening in apoE-/- mice exposed to cigarette smoke. Atherosclerosis 2004;175 7-14.

15 Ruengsakulrach P, Sinclair R, Komeda M, Raman J, Gordon I, Buxton B: Comparative histopathology of radial artery versus internal thoracic artery and risk factors for development of intimal hyperplasia and atherosclerosis. Circulation 1999;100(19 Suppl): II139-II144.

16 International Organization for Standardization: Tobacco and tobacco products - Atmosphere for conditioning and testing, 3rd ed (ISO 3402). Geneva, International Organization for Standardization, 1999.

17 International Organization for Standardization: Routine analytical cigarette-smoking machine - Definitions and standard conditions, 3rd ed (ISO 3308). Geneva, International Organization for Standardization, 2000.

-18 Vanscheeuwijck PM, Teredesai A, Terpstra PM, Verbeeck J, Kuhl P, Gerstenberg B, Gebel S, Carmines EL: Evaluation of the potential effects of ingredients added to cigarettes. Part 4: subchronic inhalation toxicity. Food Chem Toxicol 2002;40:113-131.

-19 Haussmann HJ, Anskeit E, Becker D, Kuhl P, Stinn W, Teredesai A, Voncken P, Walk RA: Comparison of fresh and room-aged cigarette sidestream smoke in a subchronic inhalation study on rats. Toxicol Sci 1998;41:100 116.

-20 Rustemeier K, Stabbert R, Haussmann HJ, Roemer E, Carmines EL: Evaluation of the potential effects of ingredients added to cigarettes. Part 2: chemical composition of mainstream smoke. Food Chem Toxicol 2002;40: 93-104.

-21 Roemer E, Stabbert R, Rustemeier K, Veltel DJ, Meisgen TJ, Reininghaus W, Carchman RA, Gaworski CL, Podraza KF: Chemical composition, cytotoxicity and mutagenicity of smoke from US commercial and reference cigarettes smoked under two sets of machine smoking conditions. Toxicology 2004;195: 31-52.

-22 Konstantinides S, Schäfer K, Thinnes T, Loskutoff DJ: Plasminogen activator inhibitor-1 and its cofactor vitronectin stabilize arterial thrombi after vascular injury in mice. Circulation 2001;103:576-583.

23 Schäfer K, Konstantinides S, Riedel C, Thinnes T, Müller K, Dellas C, Hasenfuss G, Loskutoff DJ: Different mechanisms of increased luminal stenosis after arterial injury in mice deficient for urokinase- or tissuetype plasminogen activator. Circulation 2002;106:1847-1852.

-24 Schäfer K, Schroeter MR, Dellas C, Puls M, Nitsche M, Weiss E, Hasenfuss G, Konstantinides SV: Plasminogen activator inhibitor1 from bone marrow-derived cells suppresses neointimal formation after vascular injury in mice. Arterioscler Thromb Vasc Biol 2006;26:1254-1259.

25 Raupach T, Schäfer K, Konstantinides S, Andreas S: Secondhand smoke as an acute threat for the cardiovascular system: a change in paradigm. Eur Heart J 2006;27: 386-392.

26 Gairola CG, Drawdy ML, Block AE, Daugherty A: Sidestream cigarette smoke accelerates atherogenesis in apolipoprotein E-/mice. Atherosclerosis 2001;156:49-55.

27 Heeschen C, Jang JJ, Weis M, Pathak A, Kaji S, Hu RS, Tsao PS, Johnson FL, Cooke JP: Nicotine stimulates angiogenesis and promotes tumor growth and atherosclerosis. Nat Med 2001;7:833-839.

28 Lau PP, Li L, Merched AJ, Zhang AL, Ko KW, Chan L: Nicotine induces proinflammatory responses in macrophages and the aorta leading to acceleration of atherosclerosis in low-density lipoprotein receptor (-/-) mice. Arterioscler Thromb Vasc Biol 2006;26:143149.

29 Yamaguchi Y, Matsuno S, Kagota S, Haginaka J, Kunitomo M: Oxidants in cigarette smoke extract modify low-density lipoprotein in the plasma and facilitate atherogenesis in the aorta of Watanabe heritable hyperlipidemic rabbits. Atherosclerosis 2001;156: 109-117.

30 Gurlek A, Dagalp Z, Oral D, Omurlu K, Erol C, Akyol T, Tutar E: Restenosis after transluminal coronary angioplasty: a risk factor analysis. J Cardiovasc Risk 1995;2:51-55.

31 Kotamaki M, Laustiola K, Syvanne M, Heikkila J: Influence of continued smoking and some biological risk factors on restenosis after percutaneous transluminal coronary angioplasty. J Intern Med 1996;240:293-301.

- 32 Cohen DJ, Doucet M, Cutlip DE, Ho KK, Popma JJ, Kuntz RE: Impact of smoking on clinical and angiographic restenosis after percutaneous coronary intervention: another smoker's paradox? Circulation 2001;104: 773-778.

33 Violaris AG, Thury A, Regar E, Melkert R, Serruys PW: Influence of a history of smoking on short term (six month) clinical and angiographic outcome after successful coronary angioplasty. Heart 2000;84:299-306.

34 Cutlip DE, Chauhan MS, Baim DS, Ho KK, Popma JJ, Carrozza JP, Cohen DJ, Kuntz RE: Clinical restenosis after coronary stenting: perspectives from multicenter clinical trials. J Am Coll Cardiol 2002;40:2082-2089.

35 Schillinger M, Exner M, Mlekusch W, Haumer M, Sabeti S, Ahmadi R, Wagner O, Minar E: Effect of smoking on restenosis during the 1st year after lower-limb endovascular interventions. Radiology 2004;231: 831-838.

36 Carty CS, Soloway PD, Kayastha S, Bauer J, Marsan B, Ricotta JJ, Dryjski M: Nicotine and cotinine stimulate secretion of basic fibroblast growth factor and affect expression of matrix metalloproteinases in cultured human smooth muscle cells. J Vasc Surg 1996; 24:927-934.

37 Cucina A, Sapienza P, Corvino V, Borrelli V, Mariani V, Randone B, Santoro DL, Cavallaro A: Nicotine-induced smooth muscle cell proliferation is mediated through bFGF and TGF-beta 1. Surgery 2000;127:316-322.

38 Villablanca AC: Nicotine stimulates DNA synthesis and proliferation in vascular endothelial cells in vitro. J Appl Physiol 1998;84: 2089-2098.

39 Mundal HH, Hjemdahl P, Gjesdal K: Acute effects of cigarette smoking on platelet function and plasma catecholamines in hypertensive and normotensive men. Am J Hypertens 1998;11:677-681.

40 Rubenstein D, Jesty J, Bluestein, D: Differences between mainstream and sidestream cigarette smoke extracts and nicotine in the activation of platelets under static and flow conditions. Circulation 2004;109:78-83.

41 Fusegawa Y, Goto S, Handa S, Kawada T, Ando Y: Platelet spontaneous aggregation in platelet-rich plasma is increased in habitual smokers. Thromb Res 1999;93:271-278.

42 Hung J, Lam JY, Lacoste L, Letchacovski, G: Cigarette smoking acutely increases platelet thrombus formation in patients with coronary artery disease taking aspirin. Circulation 1995;92:2432-2436.

43 Meade TW, Imeson J, Stirling Y: Effects of changes in smoking and other characteristics on clotting factors and the risk of ischaemic heart disease. Lancet 1987;2:986988.

44 Miller GJ, Bauer KA, Cooper JA, Rosenberg RD: Activation of the coagulant pathway in cigarette smokers. Thromb Haemost 1998; 79:549-553.

45 Matetzky S, Tani S, Kangavari S, Dimayuga P, Yano J, Xu H, Chyu KY, Fishbein MC, Shah PK, Cercek B: Smoking increases tissue factor expression in atherosclerotic plaques: implications for plaque thrombogenicity. Circulation 2000;102:602-604.

-46 Simpson AJ, Gray RS, Moore NR, Booth NA: The effects of chronic smoking on the fibrinolytic potential of plasma and platelets. $\mathrm{Br} \mathrm{J}$ Haematol 1997;97:208-213.

47 Geng YJ, Libby P: Progression of atheroma: a struggle between death and procreation. Arterioscler Thromb Vasc Biol 2002;22: $1370-1380$. 